\title{
Autologous hematopoietic stem cell infusion for sustained myelosuppression after BCMA-CAR-T therapy in patient with relapsed myeloma
}

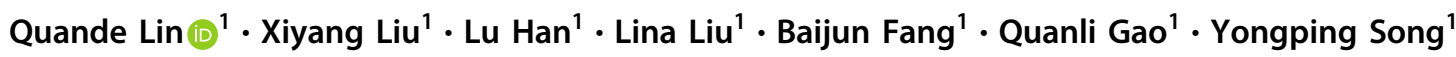

Received: 8 June 2019 / Revised: 8 August 2019 / Accepted: 13 August 2019 / Published online: 19 September 2019

(c) The Author(s) 2019. This article is published with open access

To the Editor,

Chimeric antigen receptor (CAR) T-cell targeted multiple myeloma antigens such as CD138, kappa-light chain, and Bcell maturation antigen (BCMA) as well as CD19 had been widely adopted. More and more CAR-T clinical trials for MM presented encouraging results [1-3]. However, current CAR-T treatment still faces the adverse reactions as cytokine release syndrome (CRS), myelosuppression, and other complications, especially, severe myelosuppression is often a fatal threat to patients. We adopted the stem cell infusion to promote hematopoietic recovery for a relapsed MM patient developing severe and persistent myelosuppression after CAR-T cell therapy.

A male patient with 56 years old was diagnosed with multiple myeloma, IgG, lambda type, stage II for ISS stage, and III for RISS stage. He had received nine courses of treatment including one course of PD regimen (bortezomib combined with dexamethasone) and eight courses of PAD regimen (bortezomib, epirubicin, and dexamethasone) before auto-stem cell transplantation (ASCT) and achieved the complete remission according to the evaluation criteria of the IMWG. Sufficient number of hematopoietic stem cells $(6.2 \times$ $10^{8} / \mathrm{kg}$ for $\mathrm{MNC}$ and $5.6 \times 10^{8} / \mathrm{kg}$ for $\mathrm{CD} 34^{+}$cells) were harvested. On November 23, 2017, the patient received highdose melphalan $\left(200 \mathrm{mg} / \mathrm{m}^{2}\right)$ and performed ASCT, hematopoiesis recovered 15 days after stem cell infusion.

These authors contributed equally: Quande Lin, Xiyang Liu

Quande Lin

zlyylinquande1577@zzu.edu.cn

$\bowtie$ Yongping Song

songyp357@126.com

1 Henan Cancer Hospital, Affiliated Cancer Hospital of Zhengzhou University, 127 Dongming Road, 450008 Zhengzhou, China
Lenalidomide $(25 \mathrm{mg} /$ day $\times 21$ days $)$ combined with dexamethasone $(40 \mathrm{mg} / \mathrm{week})$ as maintenance therapy started 1 month after transplantation. However, serum $\operatorname{IgG}$ and $\mathrm{M}$ spike increased, myeloma cells reached to $12.8 \%$ after 3 months of maintenance therapy. He was recruited for BCMA targeted CAR-T clinical trial (NCT03664661) under a consent form approved by the Ethics Counselor of Henan Cancer Hospital since the myeloma cells expressed BCMA antigen detected by flow cytometry (Fig. 1a). Peripheral blood mononuclear cells were collected, autologous T cells were purified and transduced with a lentiviral vector encoding a CAR incorporating an anti-BCMA scFv, 4-1BB costimulatory, and CD3-zeta T-cell activation domain. Patient underwent lymphodepletion with FC regimen (Fludarabine $25 \mathrm{mg} / \mathrm{m}^{2}$ daily for 3 days, Cyclophosphamide $500 \mathrm{mg} / \mathrm{m}^{2}$ daily for 2 days) and was infused with a total of $1.0 \times 10^{7} / \mathrm{kg}$ anti-BCMA CAR-T cells on June 16 and 17, respectively.

During the following 5 days after infusion, the patient experienced sustained fever and temperature peaked at $40.2^{\circ} \mathrm{C}$ but there was no significant increase in C-reactive protein and serum procalcitonin levels. Patient developed a grade 2 CRS according to Lee's grading system [4] as serum cytokine levels significantly elevated, including INF- $\gamma$, IL-6, and IL-10 (Fig. 1b, c). The temperature dropped to normal and the cytokine level decreased after supportive treatment for 7 days. Patient developed a grade IV of myelosuppression and was treated with granulocyte-stimulating factor, suspended red blood cells, and platelet transfusion as well as other supportive care. On day 30, BCMA expression disappeared while CAR-T cells remained detectable in BM (Fig. 1d, e). However, the patient was still at grade IV of myelosuppression until 45 days after CAR-T cells infusion. In order to promote hematopoietic recovery, autologous stem cells were infused on July 30 and August 2, respectively with a total of MNC $2.10 \times 10^{7} / \mathrm{kg}$ and $\mathrm{CD} 34^{+}$cell $1.80 \times$ $10^{6} / \mathrm{kg}$. The peripheral blood cells recovered 10 days after autologous stem cell infusion (Fig. 1c). The condition 

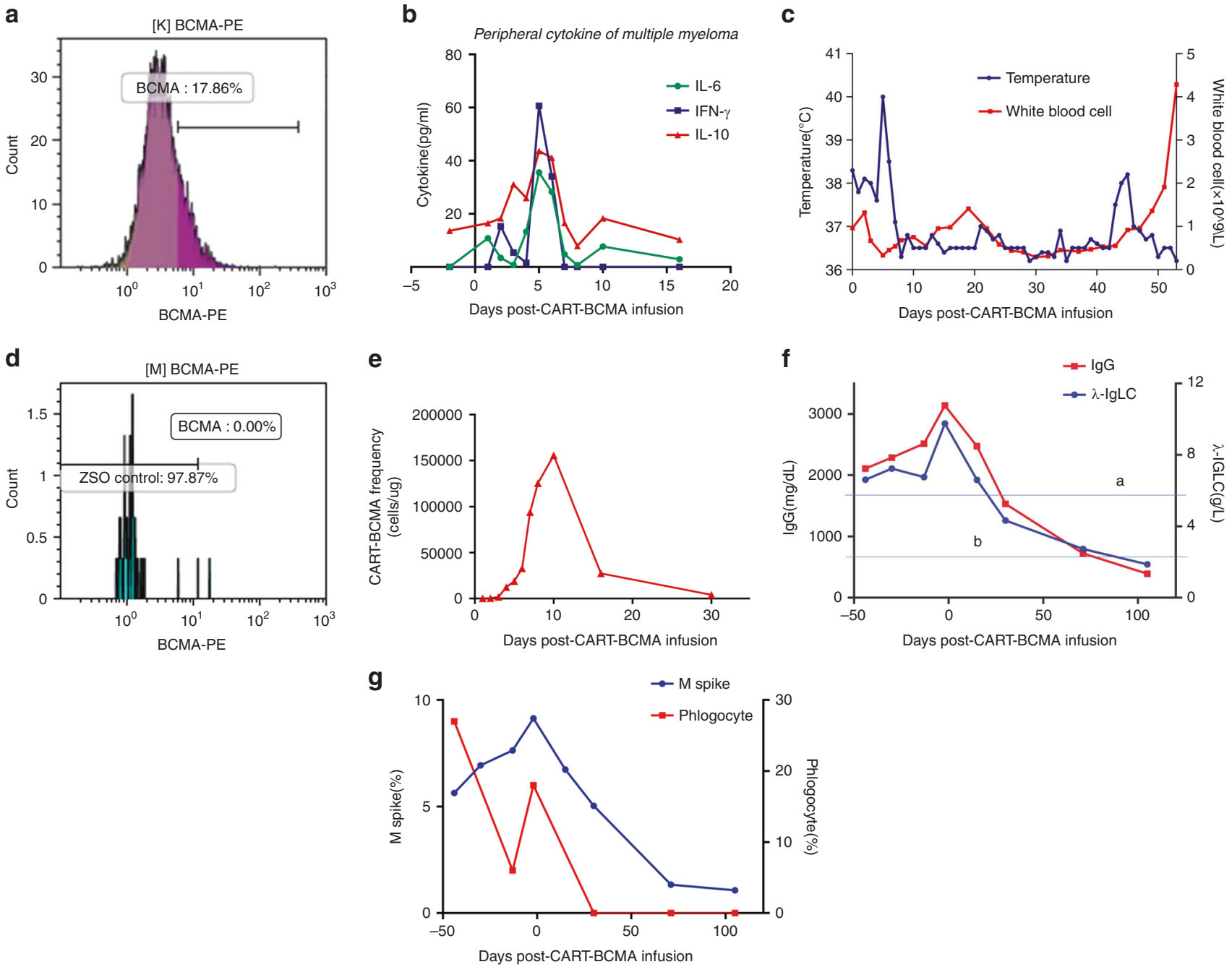

Fig. 1 a BCMA-positive myeloma cells on 17 days before CAR-T cell therapy detected by flow cytometry. b Measures of INF- $\gamma$, IL-6, and IL-10 after chimeric antigen receptor (CAR)-T BCMA cells infusion. c Changes of temperature and white blood cells after CAR-T BCMA cells infusion ( $a$ is the time of BCMA CAR-T cells infusion and $b$ is the time of stem cell infusion). d BCMA-positive myeloma cells on 30 days after CAR-T cell therapy detected by flow cytometry. e CAR-

improved gradually, and achieved VGPR 105 days after CAR-T cells infusion (Fig. 1f, g).

Previous reports of unexpected organ injury and deaths related by CAR-T cell therapy significantly limit the application of novel therapies [5]. The main adverse effects of CAR-T cell therapy include CRS, neurotoxicity, B cell aplasia, and bone marrow depression [6, 7]. B cell aplasia occurs in almost all patients treated with CAR-T therapy [8]. Myelosuppression is a common but not serious adverse reaction in CAR-T therapy. Cohen reported 11 relapsed and refractory MM patients received BCMA targeted CAR-T cells, anemia, neutropenia, lymphopenia, thrombocytopenia, hypofibrinogenemia occurred in each patient [9]. Fried analyzed the persistent severe hematologic toxicity after CD19 CAR-T cells therapy for patients with relapsed and refractory
$\mathrm{T}$ cell frequency after BCMA CAR-T cells infusion. $\mathbf{f}$ Changes of IgG and $\lambda$-IgLC before and after BCMA CAR-T cells infusion (The line a is the upper normal limit of $\operatorname{IgG}(1800 \mathrm{mg} / \mathrm{dL})$ and the line $b$ is the upper normal limit of $\lambda$-IgLC $(2.42 \mathrm{~g} / \mathrm{L}))$. $\mathrm{g}$ Changes of M spike and phlogocyte in bone marrow before and after BCMA CAR-T cells infusion

leukemia and lymphoma [10], it was indicated severe myelosuppression was more common in patients with high grade CRS and in patients receiving stem cell transplantation prior to CAR-T therapy. The patient underwent ASCT within 1 year before receiving the CAR-T cell infusion, insufficient recovery of bone marrow hematopoiesis due to intensive chemotherapy, which in turn may result in bone marrow dysfunction under hematopoietic stress.

Most myelosuppression could be restored with component transfusion and stimulating factor applications [11]. However, the case we presented here obtained mild CRS and no neurotoxicity occurred, but severe and lasting myelosuppression were observed. We found that severe myelosuppression already existed when he received infusion of CAR-T cells (Fig. 1c), this is consistent with the report [10]. Applications 
of the component transfusion and stimulating factor did not improve the myelosuppression, ultimately, it was successfully recovered by autologous stem cell infusion.

The application of autologous stem cells in the CAR-T therapy, whose effect was similar to the role of hematopoietic stem cell infusion in transplantation after high-dose chemotherapy [12], promoted the reconstruction of bone marrow hematopoietic system, avoided serious infection. Autologous stem cell infusion is also a worthwhile option when patients suffer from severe and sustained myelosuppression after treatment with CAR-T cells.

Funding The study was partly supported by the National Natural Science Foundation of China (NSFC grant no. 81470287, YPS), the Zhengzhou Science and Technology Project grant (No. 153PKJGG060, LQD), and by the Henan Province medical science and Technology Research Project (No. 201602287, LQD).

Author contributions LQ and YPS designed the study. XL drafted the manuscript. LH and QG prepared the CAR-T cells. LL and BF managed the patient. All authors participated in the revision of the manuscript.

\section{Compliance with ethical standards}

Conflict of interest The authors declare that they have no conflict of interest.

Ethics approval The study was reviewed and approved by the Ethics Committee of Henan Cancer Hospital.

Informed consent Informed consent was signed with the patient.

Publisher's note Springer Nature remains neutral with regard to jurisdictional claims in published maps and institutional affiliations.

Open Access This article is licensed under a Creative Commons Attribution 4.0 International License, which permits use, sharing, adaptation, distribution and reproduction in any medium or format, as long as you give appropriate credit to the original author(s) and the source, provide a link to the Creative Commons license, and indicate if changes were made. The images or other third party material in this article are included in the article's Creative Commons license, unless indicated otherwise in a credit line to the material. If material is not included in the article's Creative Commons license and your intended use is not permitted by statutory regulation or exceeds the permitted use, you will need to obtain permission directly from the copyright holder. To view a copy of this license, visit http://creativecommons. org/licenses/by/4.0/.

\section{References}

1. Garfall AL, Maus MV, Hwang WT, Lacey SF, Mahnke YD, Melenhorst JJ, et al. Chimeric antigen receptor $\mathrm{T}$ cells against CD19 for multiple myeloma. N Engl J Med. 2015;373: 1040-7.

2. Bo G, Xia CM, Wang HQ, Fan H, Hanren D, Wenying Z, et al. CD138-directed adoptive immunotherapy of chimeric antigen receptor (CAR)-modified $\mathrm{T}$ cells for multiple myeloma. J Cell Immunother. 2016;2:28-35.

3. Ali SA, Shi V, Maric I, Wang M, Stroncek DF, Rose JJ, et al. $\mathrm{T}$ cells expressing an anti-B-cell-maturation-antigen chimeric antigen receptor cause remission of multiple myeloma. Blood. 2016;128:1688-700.

4. Lee DW, Gardner R, Porter DL, Louis CU, Ahmed N, Jensen M, et al. Current concepts in the diagnosis and management of cytokine release syndrome. Blood. 2014;124:188-95.

5. Shih-Feng C, Anderson KC, Yu-Tzu T. Targeting B cell maturation antigen (BCMA) in multiple myeloma: potential uses of BCMA-based immunotherapy. Front Immunol. 2018; 9:1821.

6. Lee DW, Kochenderfer JN, Stetler-Stevenson M, Cui YK, Delbrook C, Feldman SA, et al. T cells expressing CD19 chimeric antigen receptors for acute lymphoblastic leukemia in children and young adults: a phase 1 dose-escalation trial. Lancet. 2015;385:517-28.

7. Maude SL, Teachey DT, Porter DL, Cui YK, Delbrook C, Feldman SA, et al. CD19-targeted chimeric antigen receptor T-cell therapy for acute lymphoblastic leukemia. Blood. 2015; 125:4017-23.

8. Porter DL, Hwang WT, Frey NV, Lacey SF, Shaw PA, Loren $\mathrm{AW}$, et al. Chimeric antigen receptor $\mathrm{T}$ cells persist and induce sustained remissions in relapsed refractory chronic lymphocytic leukemia. Sci Transl Med. 2015;7:303ra139.

9. Cohen AD, Garfall AL, Stadtmauer EA, Lacey SF, Lancaster E, Vogl DT, et al. B-cell maturation antigen (BCMA)-specific chimeric antigen receptor $\mathrm{T}$ cells (CART-BCMA) for multiple myeloma (MM): initial safety and efficacy from a phase I study. Blood. 2016;128:1147.

10. Fried S, Avigdor A, Bielorai B, Meir A, Besser MJ, Schachter J, et al. Early and late hematologic toxicity following CD19 CAR-T cells. Bone Marrow Transpl. 2019;54:1-8.

11. Yan LZ, Shang JJ, Kang LQ, Shi XL, Zhou J, Jin S, et al. Combined infusion of CD19 and Bcma-specific chimeric antigen receptor $\mathrm{T}$ cells for RRMM: initial safety and efficacy report from a clinical pilot study. Blood. 2017;130(Suppl 1):506.

12. Schwartzberg L, Birch R, Blanco R, Wittlin F, Muscato J, Tauer $\mathrm{K}$, et al. Rapid and sustained hematopoietic reconstitution by peripheral blood stem cell infusion alone following high-dose chemotherapy. Bone Marrow Transpl. 1993;11:369-74. 